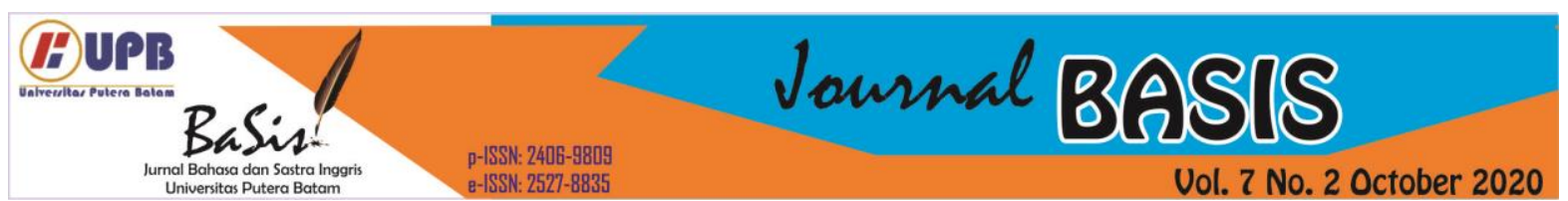

\title{
READING PORTFOLIO AS A SUPPLEMENTARY ACTIVITY TO LEVERAGE STUDENTS' READING COMPETENCY
}

\author{
Maulana Mualim ${ }^{1}$ \\ IAIN Purwokerto, Purwokerto, Indonesia \\ maulanamualim@iainpurwokerto.ac.id ${ }^{1}$ \\ Feisal Aziez ${ }^{2}$ \\ Universitas Muhammadiyah Purwokerto, Purwokerto, Indonesia \\ feisalazies@ump.ac.id ${ }^{2}$
}

\begin{abstract}
Reading as one of the skills constructing English competency has a special portion in the curriculum of English studies programs at higher education institutions. The prevalent purpose of reading classes is to enable students to grasp knowledge from any type of text written in English. This skill could be achieved through learning a series of techniques and strategies in reading, and most importantly extensive reading activities. However, the fact that the class weights as much as 2 credits (SKS) does not give sufficient training time to achieve the maximum target. Hence, an out-of-class activity should be imposed, such as reading portfolio. This paper seeks to address the criteria of a good reading portfolio, as well as the strengths and weaknesses of this supplementary reading activity given to the students of the English Education program of IAIN Purwokerto. The data are collected through documenting the findings of previous researches on the criteria of a good reading portfolio, interviewing student-sample, and observing the process of reading portfolio given to the students of IAIN Purwokerto. The results showed that a reading portfolio should contain the purpose of the course, the text liked and picked by the students, clear scoring criteria, and continuous evaluation. The strengths of reading portfolio are evoking students' interest for reading, instilling reading habit, and promoting learning autonomy and selfevaluation, the weaknesses are lack of resources, complex vocabulary and structure, and less motivation.
\end{abstract}

Keywords: Reading Skill, Reading portfolio, Reading.

\section{INTRODUCTION}

Based on SKL (standar kompetensi lulusan/the competency standard of the graduates) and CPL (capaian pembelajaran lulusan/the learning outcomes of the graduates) derived from KKNI and SN-DIKTI, students of English education major in Indonesia have to master the knowledge and the steps to build critical, logical, creative, innovative, and systematic thinking in English studies as their professional specialization (Amin, 2018). They also have to have the intellectual curiosity to solve problems in the field, these should come from within the students' intrinsic motivation that they feel fulfilled when they finally reveal the matters they are curious for (Amin, 2018). Within the tenure of the study at English Education Major, the students are required to master a set of subjects to build up their knowledge in English education, some are related to pedagogic knowledge like curriculum design, material 
development, teaching media, classroom management, and some are related to English knowledge and skills such as listening, speaking, reading, writing, structure, and pronunciation.

As one of the skills constructing the English proficiency of a student, reading skill has a special portion in the curriculum composition of English education programs. While all the four skills (listening, speaking, reading, and writing) in any schools below the university level are combined in one teaching scheme, students of English education program learn how to read English texts in special reading classes that are carried out at least in three different levels. In the context of IAIN Purwokerto, they are named as "Literal Reading", "Interpretive Reading", and "Critical Reading" (LPM, 2016).

Those classes are meant to be the training fields for the students to reach the minimum standard of reading competence formulated by the program. Through the set of reading classes starting from a low complexity level (Literal Reading/Reading I), to medium complexity level (Interpretive Reading/Reading II), to high complexity level (Critical Reading/Reading III) students are hoped to grasp theories on reading English texts and train the skills and strategies of reading such as skimming the general ideas, scanning the important details, summarizing, guessing word meanings, identifying parts of a paragraph, recognizing major and minor information, and other essential skills of reading.

However, theories will not be of any help if they are not applied in practices, exposing students to the wide range of structured knowledge should be accompanied by practices to enable the students to match their knowledge to the in-hand reality being encountered. Theories give students the researches results to the situations analyzed by the researchers whereas applying them in practices enables the students to utilize the problem-solving mechanism of the researchers to check if the theories applied to their condition. The exposure of reading practices to the students is very important because, while reading, students recall a unique set of past experiences including the theories, applied the knowledge and skills learned (cognition), and explore their interest in the text (Toprak \& Almacioğlu, 2009). Yet, the time allocated based on the curriculum is not sufficient to give the student a comfortable situation to apply the theories and enjoy their reading activity. Each reading class at IAIN Purwokerto, and most probably at all tertiary educational institutions in Indonesia, weighting 2 credits (SKS), lasts for 100 minutes. 60 minutes of them are used by the lecturer to present the theories on the skills and strategies for reading, the remaining 40 minutes were not sufficient to see the theory in a real situation (practice). Therefore, the researchers who are the teachers of the subject concluded that an out-of-class activity should be supplemented to the teaching framework of reading classes, reading portfolio could be a valuable option.

The above-mentioned condition then triggered the authors to investigate the criteria of a good reading portfolio as well as the success of this teaching technique as the students' supplementary reading activity that is done outside the classroom. The research questions of this article are therefore formulated as follow:

1. What are the components of a reading portfolio?

2. What are the strengths and weaknesses of reading portfolio? 


\section{LITERATURE REVIEW}

2.1. Reading and Extensive Reading

Reading has been an integral part of the daily lives of today's human beings. The social division does not group people to those who need reading and those who do not, everyone living today has no option but to read to assist their daily activities. Reading has been so much integrated into people's lives that not many of them are aware that reading involves a complex process, it is rather taken for granted (Rayner, Pollatsek, Ashby, \& Clifton Jr, 2012).

Unlike the skill of speaking where a communicator needs the physical appearance of the communicant, reading is closely related to self-activity meaning that in order communication through reading happens, one does not need a partner to communicate with. This notion is underlined by many researches like that of R.R Day \& Robb (2015) as stating that reading is an activity that can be done individually in times and places of the doer's favor, he/she does not need a person to make the communication through reading happens (R. R. Day \& Robb, 2015), Kim (2013) as well stated that reading is a personal activity happening in the brain of the reader, reading does not require interaction between two people or more like speaking does (Kim, 2013), and Murat et al (2012) revealed that reading is a personal activity that develops the use of language and trains a more critical way of thinking of a person (Murat, Yenal, \& Yenal, 2012). However, reading that is seen as individual or personal activity, in fact, involves a lot of interaction between the reader, the text, and as such the writer. Through a set of mental processes including predicting, acknowledging, comparing, evaluating, and decision-making a reader strives to understand the ideas addressed by the writer (Demiroz, 2007; Grabe \& Stoller, 2020; Shihab, 2011).

During a reading activity, various processes happen in the brain one after the others (simultaneously). First, a reader recognizes words very quickly in the text, then, while recalling the known words and registering the unknown ones in his/her working memory, he/she slices the sentence structures into chunks of phrases and clauses to assemble the most logical meaning of the chunks and the whole structure. Later on, the information acquired through linguistic analysis is linked to the activated knowledge of the long term memory (LTM) as the background knowledge (Grabe \& Stoller, 2020). That is how the process of comprehending texts happens, the purpose of every reading activity is to figure out new insights with the help of the pieces of knowledge stored in the LTM (Rayner et al., 2012), the new insights are also stored in the LTM and will be needed again to understand the texts in the next reading activities. Reading activity involves internal and external factors, the internal factors are intellectual, language skills, psychological, environment, and experience while the external factors are the facility like books and place and lighting condition. To comprehend well, a learner should possess association, conception, perception, syntactic, semantic, and cognitive abilities (Sartika, Afifah, \& Anggraini, 2020).

Extensive reading is an approach to second/foreign language reading activity in which a learner reads a large amount of reading material for pleasure in order to build the speed and fluency of reading rather than examining every point of the text. It is comparable with intensive reading in which a learner reads a certain text deeply, understands every point that might be questioned after the reading activity, examines the vocabularies, 
sentences, and structures. Many terms are coined to refer to this reading activity namely pleasure reading, wide reading, self-selected-reading, and free voluntary reading (Ng, Renandya, \& Chong, 2019). During the activity, a language learner only needs a material that matches their interest and level of proficiency. He/she are not given materials that are not interesting to them, if he/she is fancy reading narrative texts then books of tales, folktales, fairy tales, and novel are good for him/her, as such if they are not fond of reading descriptive texts, then he/she should not be given newspapers, reports, scientific books, and any other books with descriptive text. Because, the ultimate goal of this activity is to read for general understanding and enjoyment (R. R. Day \& Robb, 2015).

Many programs of English as a second or foreign language (ESL/EFL) have featured extensive reading in their classes. Many research results have proven that reading a large amount of simple and attractive materials/matching the readers' level improve foreign/second language skill especially in vocabulary (Stoeckel, Reagan, \& Hann, 2012). Ng et al stated that the easy and comprehensible books with various genres allow the learners to enjoy the reading activity and improve the reading competency at the same time (Ng et al., 2019)

Day and Bamford (2002) formulated 10 conditions as the key ingredients for an extensive reading activity to be successful, they also encourage teachers to implement as many conditions as possible in their teaching programs. They are:

1. The reading material is easy

2. A variety of reading material on a wide range of topics is available.

3. Learners choose what they want to read.
4. Learners read as much as possible.

5. Reading is for pleasure, and to gain information and general is

6. Reading is the reward itself.

7. Learners generally read quickly and not slowly.

8. Reading is silent and individual.

9. Teachers orientate and provide guidance to students.

10. The teacher models being a reader. (R. Day, 2015)

\subsection{Reading Portfolio}

Naturally, the concept of portfolio is originated from the Fine Art field, they are used to represent the artists' works (Hosni, 2017). Portfolio is defined by Javanmard \& Farahani as a compilation of works a student collects in any forms of container like a journal, file folder, box, or else aimed to show his learning progress in a given time (Javanmard \& Farahani, 2012), it is viewed by Teddy Fiktorius as an alternative scoring technique worth applying in English classes, it is a revolutionary means of assignment and scoring that is more realistic compared to the traditional patterns (Fiktorius, 2012). Through reading portfolio, students are given freedom in acknowledging their needs and fulfilling them with full courage coming from within (intrinsically motivated), and later on expressing what they get in a piece of work. Jokha Al Hosni supported this argument as reporting that many have seen the superiority of reading portfolio for employing strategies that ask students to reveal their inclination, compared to the traditional assessment in which students are graded based on their registers to a strange issue rather than on what they like to recall and reproduce. Portfolio provides opportunities for the students to perform their works independently autonomously without encountering 
stress (Hosni, 2017). The freedom given to them in choosing their own text and their best techniques in exploiting the text, students become more responsible in their learning development (Moore, Knight, \& Kiburz, 2014).

Reading portfolio allows students to watch their development in reading proficiency that is built over time. In other words, besides the freedom in picking materials that they think are suitable for them, they also can have a collaborative assessment with their teachers, students watch their works, see the pitfalls and shortcomings, and then are expected to revise them in the next work by following the advice of the teacher. This collaborative assessment would surely tighten the ties between the students and the teacher, it is constructive rather than judgmental for the students (Valencia, 1990).

\subsection{Previous Studies}

Teaching reading skills through portfolio is not something new to the horizon of English language teaching, it has attracted the attention of many researchers from time to time. The personalized concept of the technique and the need for extensive reading has made this technique interesting to investigate. The success of this technique in a research setting has led others to prove it in their research settings.

Nick Moore, Gillian Knight, and Claudia Kiburz (2014) through their research entitled "Developing an Assessed Reading Portfolio to Improve Reading Habits and Raise Test Results" found that reading portfolio is one of the effective teaching techniques to instill the reading habit to the students of Khalifa University (United Arab Emirate) and raise their score in the reading examinations, the results showed that students who followed the instructions in compiling the reading portfolio well gained good results in the reading examinations compared to those who did not perform well in the reading portfolio project (Moore et al., 2014).

Andrzej Cirocki in his literary study entitled "The Reading Portfolio: a Tool for Both Learning and Assessment in the Secondary School EFL Classroom" examined the theories, concepts, and findings of several academic works as an addition to the references for secondary teachers to apply reading portfolio technique in holding the reading tests. Through deep literary investigation, Cirocki found that reading portfolio could be used as both a teaching technique and an assessment tool. Reading portfolio has the potentials to shape students' critical thinking, problem-solving, learning autonomy, creativity, and growth. The technique was found to be rewarding and fruitful although it requires high commitment on both the students and the teacher (Cirocki, 2013).

Mahshid Rostami Charvade, Shahrokh Jahandar, and Morteza Khodabandehlou conducted experimental research to 50 EFL students of intermediate level of a private Englis language institution, the students were divided randomly into two groups namely experimental and control groups. Through their research report entitled "The Impact of Portfolio Assessment on EFL Learners' Reading Comprehension Ability", Charvade, et. al. revealed that the students who received an experiment of reading portfolio had better performance in reading activity rather than the students who received traditional teaching technique. Based on the data analysis, Charvade et al suggested that reading portfolio empowers students' reading comprehension competency (Charvade, Jahandar, \& Khodabandehlou, 2012). 
Ting-Ting $\mathrm{Wu}$, Yueh-Min Huang, Han-Chieh Chao, and Jong Hyuk Park through their article entitled "Personalized English reading sequencing based on learning portfolio analysis" explained that reading portfolio as a means of situated learning enables the students to make direct contacts with real-world objects, get a deep impression of the learning materials, and find the link between the real objects and the materials. The research, which combined quantitative and qualitative evaluations, revealed that the reading portfolio with personalized materials could assist the students in developing their reading competences since they immerse themselves in the materials (Wu, Huang, Chao, \& Park, 2014).

Based on the above-mentioned previous studies, this research is significant to the horizon of English Language Teaching in general and the teaching of the reading skill in particular since it seeks to reveal its implementation to the learning activities of IAIN Purwokerto students. The results of this research fill in the gaps of the four previous-researches mentioned above, the results mostly add information on the criteria of a good reading portfolio, and also show the success of its implementation to the students of IAIN Purwokerto.

\section{RESEARCH METHOD}

The data of this study are collected through documentation technique in the form of an in-depth investigation of reliable resources to unfold the criteria of a good reading portfolio. Other data which are responses of the studentsample generated through an interview on their experience in the application of reading portfolio (Silverman, 2016), finally an observation is made to analyze whether or not the reading portfolio technique given to the students so far enhances their fondness to reading thus increasing their proficiency in reading. Several students of the first year taking the courses of Literal Reading are picked as the informants to the interview through the procedure of random sampling (Merriam, 1998; Silverman, 2016).

\section{RESULT AND DISCUSSION}

\subsection{Components in a Reading Portfolio}

Since the nature of portfolio is in the art studies, Coombe and Barlow reveal that there is no such thing called as basic guidelines to design a portfolio (Coombe $\&$ Barlow, 2004). Portfolio is, like any other artworks, very personal, it reflects the identity and uniqueness of the creator, it tells the stories of the creators' creativity development over time, and thus, there is no standard to refer to. However, since portfolio in this regard is adopted to enhance the reading activity, every school, institution, or even teacher needs to set criteria in assessing students' works, the criteria of one school may therefore be different from the others. Nevertheless, no matter how different the criteria of one to another school are, a reading portfolio has to have at least the components of ongoing, cooperative, multi-dimensional, and authentic assessment (Coombe \& Barlow, 2004; Yurdabakan \& Erdogan, 2009). Moore et. al. on the other hand reveals that when compiling the criteria that will be assessed in the portfolio, teachers should take several factors into account, namely 1) Course aims and outcome, in which teachers explain what are the goals of making the portfolio and what are the products expected to be produced by the end of the portfolio period 2) Content, the teachers explain the important points that should be complied with by the student in the portfolio 3) Quantity, the teachers explain the number of words of pages 
that should be read by the students 4) Activities, the teachers explain the activities that should be done by the students 5) Consistency, the teachers explain that students should focus (consistent) during the composition his/her portfolio, that will take a long time to do 6) Assessment, the teachers should provide evaluation to the works submitted by the students over time and 7) Organization \& Presentation, the teachers explain how the portfolio should be compiled and how they should be presented later (Moore et al., 2014).

Pinar at. al. stated that during the process of portfolio, learners are supposed to undergo four stages of reflection, namely: 1) regressive, 2) progressive, 3) analytical, and 4) synthetical. In the regressive stage, learners recall their past memories regarding the given topic. Afterward, they relate these memories to the future via "imagination and potentiality" in the stage of progressive, they flashback to the past, capture the memories, and reflect them to the presented topic. In the analytical stage, the learners examine the connection of the past memories and the future condition in light of the current situation. Finally, in the synthetical stage, the learners try to compose "a sense of meaning in the present" based on the continuity. Pinar et al. pointed out that through portfolio projects, the learners use their own life, identity, character, social backgrounds, etc. as a means to help them engaged with the curriculum, rather than making the formal curriculum stated by others (Pinar, Reynolds, Slattery, \& Taubman, 1995).

Valencia (1990) underlines that using portfolio in reading activity is very rewarding, it corresponds to every teacher's desire in seizing the students' potentials and capitalize them, it enables the teachers to evaluate the students' reading proficiency through many different ways, its integrity and validity in the assessment are not possessed by any other types of assessment. Besides that, portfolio has theoretical and pragmatic reasons underlying its importance in reading assessment summarized in four principles, namely: 1. Sound assessment of the authentic relation between task, text, and context, e.i. in assessing reading, teachers should formulate an instrument that mirrors the comprehensive points of reading as an interactive process. Students should be evaluated through authentic reading activities, not in an isolated space and time that does not resemble a real reading. 2. Assessment must be a continuous process, it should tell the story of the reading development, it should assess the process rather than the product. 3 . Multidimensional assessment, other dimensions constructing students' reading proficiency such as metacognitive and strategies, voluntary reading, and interest and motivation should also be evaluated, ignoring these dimensions in reading assessment means accepting the drawbacks in reading. 4. Collaborativereflective assessment, portfolio will unite teachers and students to realize successful reading classes, students are not judges for the competences that they are not capable at yet, but it is rather taken as a reflection to both the students and the teachers. (Valencia, 1990)

\subsection{The Strengths and Weaknesses of Reading Portfolio}

In general, respondents gave positive responses to the idea of applying reading portfolio as a supplementary session to the classes. However, since the technique was done in a traditional manner in which they were to find a book rather than the 
online one, respondents expressed their problems in fulfilling the assignment.

All respondents stated that they had mixed-feeling upon learning that reading portfolio would be applied to the classes, they were interested in the technique for they believe it could instill reading habits to them so that they could enhance their English reading proficiency. However, they were anxious since the activity would double their efforts for the classes. Some respondents stated that it was hard to find books in English in the city of Purwokerto, especially the second-hand ones that cost fairly cheap. The only store they could access was the one with the expensive price they hardly afford it. Others stated that since the store was only one they did not get many options to choose, they could not find the book that they wanted to read.

Based on the interview and observation, the author could underline some strengths of reading portfolio as follow:

\section{a. Interest}

Although there were not many variations of books available around them, students were excited to show their chosen books to the class, some of the students were aware that their chosen books are world-renown novels, some were not aware until the lecturer told them so. The important point of portfolio is the students' feeling of pride that they were the only ones knowledgeable on the book they had chosen, and with pride, they explained what they had in their portfolio. In many ways, this finding has aligned well with the theories stated by ( $\mathrm{Ng}$ et al., 2019) and (R. R. Day \& Robb, 2015) that extensive reading should be done based on the learners' interest.

b. Reading Habit Instilment

The portfolio imposed on them was claimed to have built their awareness that in order to gain comfort in reading
English texts they need to read at least one page in a day, and they need to go on reading when they encountered unknown words or complex structures. Through portfolio, many students believed to have developed some levels in their reading habit. This finding is similar to that of (Moore et al., 2014) who have implemented reading portfolio to their classes at Khalifa University in Unated Arab Emirates.

c. Learning Autonomy

Through reading portfolio, students were trained to recognize their needs and fulfill them. They were able to choose the text on topics that they were curious about and to discover the mysteries in the material. In that sense, they could learn to read English texts autonomously. All respondents stated that reading portfolio gave them the freedom to pick any material to read, therefore it enhances their learning autonomy. This finding has proven the theories of (R. Day, 2015), also has shown similarities with the findings of (Cirocki, 2013) and (Hosni, 2017).

\section{d. Self-Evaluation}

They surely found troubles in reading the texts, they had to find out the solutions of the problems, they will be graded in every portfolio they sent to the lecturer, so that they are able to watch the development of their reading ability over time, the norm should be from low marks to high marks, so they evaluate their reading ability weekly and the problem they had in the previous week should not be repeated, this finding proves the theory explained by (Valencia, 1990).

Along with the strengths, students also encountered weaknesses of the technique, namely:

a. Lack of Resource

As mentioned earlier, there were not many variations students could opt in the 
city of Purwokerto. Most available books in English are in the form of novel, and most of them are classic novels which are interesting for some students but not for some others. The libraries found in the city were also seen to be lack of books that they are fond of. Besides that, they also found linguistic constraints as the classic novels use the classic style of English, which are very complicated for the level of first-year university. As a result, the students picked the available books with a lack of interest to them. The findings of ( $\mathrm{Wu}$ et al., 2014) could be a solution for this obstacle, by using RFID technology, they managed to provide the learners with extensive digital resources according to the students' location.

b. Complex vocabulary and sentence structure

The first weakness contributes to the emergence of the second one. The books that they half-heartedly picked contain too many vocabularies that are not used on a daily basis that hinder them in comprehending the sentences. Besides that, some structures were also found very complicated, these made the students read very slow and may lead them in misunderstanding. As a result, they lack the confidence to report the reading in their portfolio. The findings do not comply with the theory of (R. R. Day \& Robb, 2015) and (Stoeckel et al., 2012) who stated in their finding that the texts should be in accordance with the learners' level of proficiency.

c. Less Motivation

The accumulation of complex structure, unfamiliar words, old English style, and that most of the books are classic novels discourage students to go on their reading. Many expressed that the reading activity imposed on them was like a big burden to their shoulder that bores them and even intimidates them. They identified less and less motivation in reading novels. This situation emerged because the failure in implementing the principals of reading portfolio formulated by (Coombe \& Barlow, 2004; Hosni, 2017; Moore et al., 2014; Valencia, 1990)

\section{CONCLUSION}

Based on the literary investigation and case study at IAIN Purwokerto, the author concludes the following facts. A reading portfolio should contain the purpose of the course, the text should be chosen based on the interest of the students and the purpose of the course, lecturers are to formulate clear scoring criteria, and give feedback to students' works. Despite the advantages that reading portfolio carries, the implementation of this technique in the reading classes at IAIN Purwokerto was unfortunately not successful. Some strengths of reading portfolio experienced by the students are they are interested in doing the portfolio and presenting their works to their peers, they also felt by doing the portfolio they are habituated to reading (reading habit instilment), the students also felt that they were able to learn the texts and strategies to read autonomously, finally, the students could evaluate themselves in reading (self-evaluation). The weaknesses of reading portfolio encountered by the students are lack of resources in the town they live in, complex vocabulary and structure found in the books available around the students, and less motivation for the combination of the two previously mentioned factors.

\section{REFERENCES}

Amin, K. (2018). Standar Kompetensi Lulusan (SKL) dan Capaian Pembelajaran Lulusan (CPL) Program Studi Jenjang Sarjana pada Perguruan Tinggi 
Keagamaan Islam dan Fakultas Agama Islam (FAI) pada Perguruan Tinggi. Retrieved from http://diktis.kemenag.go.id/NEW/f ile/dokumen/2815324462893280L FULL.pdf

Charvade, M. R., Jahandar, S., \& Khodabandehlou, M. (2012). The Impact of Portfolio Assessment on EFL Learners' Reading Comprehension Ability. English Language Teaching, 5(7), 129139.

https://eric.ed.gov/?id=EJ1079679

Cirocki, A. (2013). The reading portfolio: A tool for both learning and assessment in the secondary school EFL classroom. International Journal of Innovation in English Language Teaching and Research, 2(2), 223.

Coombe, C., \& Barlow, L. (2004). The reflective portfolio: Two case studies from the United Arab Emirates. English Teaching Forum, 42(1), 18-23.

Day, R. (2015). Extending Extensive Reading. Reading in a Foreign Language, 27(2), 294-301.

Day, R. R., \& Robb, T. (2015). Extensive reading. Language Learning beyond the Classroom, 3-12.

Demiroz, H. (2007). Critical reading its key concepts, and importance in foreign language education. Jokkef, 16, 66-78.

Fiktorius, T. (2012). Portfolio assessment in English language teaching (ELT). Academia. Edu.

https://www.academia.edu/2324141/Port
folio_Assessment_in_English_Lan guage_Teaching_ELT_

Grabe, W., \& Stoller, F. L. (2020). Teaching and researching reading (Third Edit). New York: Routledge.

Hosni, J. Al. (2017). New Perspective on Portfolios in EFL Classrooms: Portfolio as an Autobiographical Text. Studies in English Language Teaching, 5(4), 771. https://doi.org/10.22158/selt.v5n4p 771

Javanmard, Y., \& Farahani, H. (2012). Investigating Using Portfolio Assessment and Learning English Language in Qom Secondary Schools. Global Journal of Human Social Sciences, 12, 53.

Kim, Y. H. (2013). The Effect of Taskbased Cooperative Learning Method on EFL Learners' Reading Anxiety in Reading Class. English Literature, 18(1), 379-412.

LPM, I. P. (2016). Panduan Akademik IAIN Purwokerto 2016-2017. Purwokerto: IAIN Purwokerto.

Merriam, S. B. (1998). Qualitative Research and Case Study Applications in Education. Revised and Expanded from "Case Study Research in Education." San Fransisco: Jossey-Bass Publishers.

Moore, N., Knight, G., \& Kiburz, C. (2014). Developing an assessed reading portfolio to improve reading habits and raise test results Developing an Assessed Reading Portfolio to Improve Reading Habits and Raise Test Results. 214-237. 
Murat, Ö., Yenal, T. H., \& Yenal, A. (2012). Opinions of the physical education and sports candidate teachers about reading 1 . International Journal of Human Science.

Ng, Q. R., Renandya, W. A., \& Chong, M. Y. C. (2019). Extensive reading: Theory, research and implementation. Teflin Journal, 30(2), 171-186. https://doi.org/10.15639/teflinjourn al.v30i2/171-186

Pinar, W. F., Reynolds, W. M., Slattery, P., \& Taubman, P. M. (1995). Understanding curriculum: An introduction to the study of historical and contemporary curriculum discourses (Vol. 17). Peter Lang.

Rayner, K., Pollatsek, A., Ashby, J., \& Clifton Jr, C. (2012). Psychology of reading (Second Edi). New York: Psychology Press.

Sartika, F. D., Afifah, N., \& Anggraini, Y. (2020). the Correlation Between Students' Reading Habit and Their Reading Comprehension. Jurnal Basis, 7(1), 207. https://doi.org/10.33884/basisupb. v7i1.1856

Shihab, I. A. (2011). Reading as critical thinking. Asian Social Science, 7(8), 209-218. https://doi.org/10.5539/ass.v7n8p2 09

Silverman, D. (2016). Qualitative research. Los Angeles: Sage.

Stoeckel, T., Reagan, N., \& Hann, F. (2012). Extensive reading quizzes and reading attitudes. TESOL Quarterly, 46(1), 187-198.

Toprak, E. L., \& Almacioğlu, G. (2009). Three reading phases and their applications in the teaching of english as a foreign language in reading classes with young learners. Journal of Language and Linguistic Studies, 5(1), 20-36.

Valencia, S. (1990). Assessment: A portfolio approach to classroom reading assessment: The whys, whats, and hows. The Reading Teacher, 43(4), 338-340.

Wu, T.-T., Huang, Y.-M., Chao, H.-C., \& Park, J. H. (2014). Personlized English Reading Sequencing Based on Learning Portfolio Analysis. Inf. Sci., 257, 248-263. https://doi.org/10.1016/j.ins.2011.0 7.021

Yurdabakan, I., \& Erdoğan, T. (2009). The Effects of Portfolio Assessment on Reading, Listening and Writing Skills of Secondary School Prep Class Students. Journal of International Social Research, 2(9). 
